\title{
Human dental pulp stem cell adhesion and detachment in polycaprolactone electrospun scaffolds under direct perfusion
}

\author{
A. Paim ${ }^{1,2,3}$, D.I. Braghirolli ${ }^{3}$, N.S.M. Cardozo ${ }^{2}$, P. Pranke ${ }^{3,4}$ and I.C. Tessaro ${ }^{1}$ \\ ${ }^{1}$ Laboratório de Separação por Membranas, Departamento de Engenharia Química, Universidade Federal do Rio Grande do Sul, \\ Porto Alegre, RS, Brasil \\ ${ }^{2}$ Laboratório de Simulação, Departamento de Engenharia Química, Universidade Federal do Rio Grande do Sul, \\ Porto Alegre, RS, Brasil \\ ${ }^{3}$ Laboratório de Hematologia e Células-Tronco, Faculdade de Farmácia, Universidade Federal do Rio Grande do Sul, \\ Porto Alegre, RS, Brasil \\ ${ }^{4}$ Instituto de Pesquisa com Células-Tronco, Porto Alegre, RS, Brasil
}

\begin{abstract}
Cell adhesion in three-dimensional scaffolds plays a key role in tissue development. However, stem cell behavior in electrospun scaffolds under perfusion is not fully understood. Thus, an investigation was made on the effect of flow rate and shear stress, adhesion time, and seeding density under direct perfusion in polycaprolactone electrospun scaffolds on human dental pulp stem cell detachment. Polycaprolactone scaffolds were electrospun using a solvent mixture of chloroform and methanol. The viable cell number was determined at each tested condition. Cell morphology was analyzed by confocal microscopy after various incubation times for static cell adhesion with a high seeding density. Scanning electron microscopy images were obtained before and after perfusion for the highest flow rate tested. The wall pore shear stress was calculated for all tested flow rates $(0.005-3 \mathrm{~mL} / \mathrm{min})$. An inversely proportional relationship between adhesion time with cell detachment under perfusion was observed. Lower flow rates and lower seeding densities reduced the drag of cells by shear stress. However, there was an operational limit for the lowest flow rate that can be used without compromising cell viability, indicating that a flow rate of $0.05 \mathrm{~mL} / \mathrm{min}$ might be more suitable for the tested cell culture in electrospun scaffolds under direct perfusion.
\end{abstract}

Key words: Cell adhesion; Perfusion; Shear stress; Stem cell; Electrospun scaffolds

\section{Introduction}

In tissue engineering, scaffolds are used as substitutes for damaged tissue and act as a support for cell proliferation, differentiation, and migration. In order to promote the formation of natural extracellular-matrix, a scaffold must be designed with appropriate biocompatibility, biodegradability, architecture, and mechanical properties (1).

An important class of scaffolds for tissue engineering is based on electrospun polymer-based structures comprising solid microfibers or nanofibers, which can present high packing density and interconnected pore network (2). Nanofiber scaffolds favor higher mesenchymal stem cell viability than smooth surfaces (3). However, nanofiber scaffolds usually present small pores (4) that can hinder cell infiltration through three-dimensional structures (2). On the other hand, microfiber scaffolds can provide structures with bigger pores, allowing the cell migration and colonization inside the matrix (5).
Perfusion culture systems enhance mass transfer in scaffold-containing bioreactors and provide increased nutrient transport and cell viability (6), migration (7), growth, and differentiation (8). In addition, perfusion bioreactors can reduce the accumulation of toxic metabolites and degradation byproducts and the polymer degradation rate (9). Nevertheless, high shear stress can provoke cell detachment followed by cell death (10). Consequently, the cell number in three-dimensional (3D) scaffolds under perfusion is influenced by the cell detachment provoked by shear stress (11) and the capability of the cells to remain adhered to the scaffold and to proliferate, differentiate, and migrate is strongly dependent on the flow rate and the pore size employed. This is important because in order to obtain a homogeneous and effective regeneration of damaged tissue, it is essential to produce a biomaterial with an adequate cell number for implantation.

Correspondence: A. Paim: <agata@enq.ufrgs.br> 
Therefore, it is necessary to quantify the cell drag and the final cell number in perfusion bioreactors to produce tissue substitutes that fit the quality standard required in a medical environment. Despite this, many studies on perfusion systems based on 3D scaffolds focus on the flow rate and shear stress effect on nutrient transport and stem cell proliferation and differentiation (12-14), without evaluating the cell detachment from the scaffold.

This work addressed the reduction of the shear stress effects inside the scaffold pores under perfusion to produce cellularized electrospun structures for clinical application. An investigation was made of flow rate and shear stress under direct perfusion in polycaprolactone electrospun scaffolds on human dental pulp stem cell detachment. The influence of the adhesion time on cell adhesion and detachment under static conditions was also evaluated. Different seeding densities were tested under perfusion to evaluate the detachment.

\section{Material and Methods}

\section{Scaffold production}

The scaffolds were produced in an electrospinning apparatus with temperature and humidity control (EC-CLI, IME Technologies, Netherlands). A $16 \% \mathrm{w} / \mathrm{w}$ solution of polycaprolactone (Sigma-Aldrich, USA; Mw 70-90 kDa) in a chloroform:methanol 9:1 vol\% mixture was electrospun at $38 \%$ humidity, $19^{\circ} \mathrm{C}, 35 \mathrm{~cm}$ distance between the needle and the collector, flow rate of $0.1 \mathrm{~mL} / \mathrm{min}$, and voltage of $17 \mathrm{kV}$. The scaffolds were cut into $16 \mathrm{~mm}$ diameter disks and sterilized by ultraviolet radiation (UV) for $1 \mathrm{~h}$.

\section{Cell isolation and expansion}

The pulp of human deciduous teeth was used to obtain dental pulp stem cells with the approval of the Research Committee and the Ethics Committee of the Universidade Federal do Rio Grande do Sul (project No. 33177214.1. 3001.5330), according to the methodology described by Werle et al. (15). Human deciduous teeth with physiologic root resorption were extracted and immersed in DMEM (Dulbecco's modified Eagle's culture medium)/Hepes (Sigma-Aldrich), supplemented with $10 \%$ fetal bovine serum (FBS; Gibco, USA), $100 \mathrm{U} / \mathrm{mL}$ penicillin and $100 \mathrm{mg} / \mathrm{mL}$ streptomycin (Gibco), for transportation. The dental pulp tissue was removed with the use of endodontic instruments and the cells were isolated from the pulp by a mechanic and enzymatic process. The isolated cells were incubated for $24 \mathrm{~h}$ at $37^{\circ} \mathrm{C}$ and $5 \% \mathrm{CO}_{2}$. The primary cultures and further passages were subcultured when a confluence of $90 \%$ was reached, with medium exchange every 3 or 4 days. Five primary culture cells (between the third and eighth passages) were used in this work. The cells were characterized as mesenchymal stem cells in terms of immunophenotypic profile and differentiation potential, as presented in the Supplementary Material (Table S1 and Figure S1, respectively).

\section{Cell viability}

A colorimetric assay with water-soluble tetrazolium salts (WST-8, [2-(2-methoxy-4-nitrophenyl)-3-(4-nitrophenyl)5-(2,4-disulfophenyl)-2H-tetrazolium]) was used to determine the number of viable cells. As opposed to other common colorimetric assays, the WST-8 assay does not kill the cells, which allows continuous culturing of the cells, performing other assays with the living cells, and preserving the samples after the measurements. For this test, the culture medium was removed and the scaffolds were incubated with $20 \mu \mathrm{L}$ of Cell Counting Kit-8 solution (CCK-8, Sigma-Aldrich) and $180 \mu \mathrm{L}$ of fresh culture medium at $5 \%$ $\mathrm{CO}_{2}$ and $37^{\circ} \mathrm{C}$ for $1 \mathrm{~h}$. The absorbance was read in $450 \mathrm{~nm}$ in a microplate reader (Multiskan FC, Thermo Scientific, USA). Standard curves relating absorbance readings $(450 \mathrm{~nm})$ with cell number were constructed for each cell culture to determine the viable cell number.

\section{Cell morphology}

After the viability assay, the scaffolds were washed with phosphate-buffered saline solution (PBS) and fixed with $4 \%(w / v)$ paraformaldehyde (PFA; Sigma-Aldrich) for $30 \mathrm{~min}$. The PFA was then removed and the scaffolds were washed again with PBS. Cytoskeleton and nuclei cells were stained with $50 \mu \mathrm{g} / \mathrm{mL}$ rhodamine-phalloidin (Molecular Probes, USA) for $40 \mathrm{~min}$ and $0.5 \mu \mathrm{g} / \mathrm{mL} \mathrm{4}$, 6-diamidino2-phenylindole (DAPI) for $5 \mathrm{~min}$, respectively, for further imaging using a confocal microscope (Olympus FV1000, Japan). For scanning electron microscopy (SEM; JEOL JSM 6060, Japan), the scaffolds were washed with PBS, fixed with $3 \%$ glutaraldehyde and dehydrated in graded ethanol baths before being sputtered with gold and imaged.

\section{Scaffold properties}

The porosity of scaffolds was calculated from the volume of fibers and the total volume of the scaffold. The volume of the fibers $\left(\mathrm{V}_{\text {fibers }}\right)$ of the scaffold was determined by dividing the weight of the scaffold by the PCL density, and the total volume of the scaffold $\left(\mathrm{V}_{\text {total }}\right)$ was determined taking into account its geometry. The total porous fraction $(\theta)$, thereby, is given by Equation 1 .

$$
\theta=\frac{V_{\text {total }}-V_{\text {fibers }}}{V_{\text {total }}}
$$

The average shear stress on the wall of the pores was calculated considering a cylindrical pore approximation (16), using Equation 2.

$$
\sigma=\frac{8 \mu Q}{d_{p} \theta \pi\left(\frac{D}{2}\right)^{2}}
$$

where $\mu$ is the medium viscosity (Pa.s) (similar to that of water at $37^{\circ} \mathrm{C}$ ), $d_{p}$ is the pore diameter $(\mathrm{m})$ (measured through analysis of SEM images of the scaffolds with the software ImageJ), $Q$ is the flow rate $\left(\mathrm{m}^{3} / \mathrm{s}\right)$, and $D$ is the scaffold diameter $(\mathrm{m})$. 


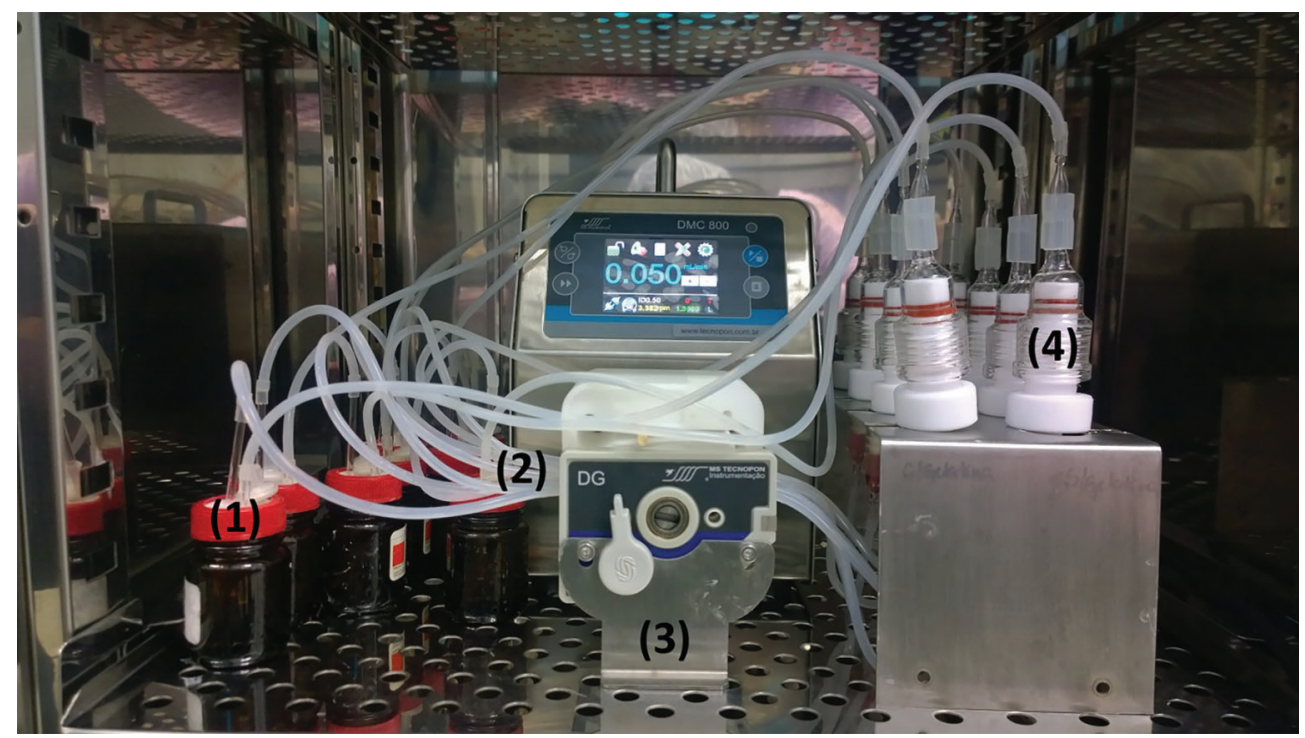

Figure 1. Perfusion bioreactor system: medium reservoir (1), silicon tubing (2), peristaltic pump (3), and perfusion chamber (4).

\section{Cell adhesion and drag}

Initially, $1.5 \times 10^{5}$ or $0.5 \times 10^{5}$ cells were seeded in each scaffold and the volume was completed to $1 \mathrm{~mL}$ with culture medium in each well. Different adhesion times $3 \mathrm{~h}(17), 6 \mathrm{~h}(18)$, and $24 \mathrm{~h}(19,20)$ - were used for mesenchymal stem cell attachment in the 3D scaffolds. In order to evaluate the impact of the adhesion time on cell adhesion and morphology, cells were then incubated at $5 \% \mathrm{CO}_{2}$ and $37^{\circ} \mathrm{C}$ for 3,6 , and $24 \mathrm{~h}$ for cell adhesion. Three cell cultures were used in this experiment and the number of scaffolds analyzed for each adhesion time was 3 per culture.

Firstly, the scaffolds seeded with $0.5 \times 10^{5}$ cells and incubated for 3,6 , and $24 \mathrm{~h}$ were perfused with culture medium for $18 \mathrm{~h}$ at $0.05 \mathrm{~mL} / \mathrm{min}$, in order to evaluate the adhesion strength of each adhesion time group. Two scaffolds per culture were analyzed for each adhesion time under flow and three cell cultures were used. The bioreactor system used for the culture medium perfusion is shown in Figure 1.

Considering that increased cell adhesion and spreading have been reported in the literature with longer adhesion times (19-21), the effect of the flow rate in cell detachment was evaluated following an adhesion time of $24 \mathrm{~h}$ under static conditions, to guarantee that the cells were fully adhered and would not be detached with flow perfusion due to poor adhesion. In addition, the perfusion time used in further experiments was changed from 18 to $24 \mathrm{~h}$ to guarantee that maximum cell drag was achieved. Therefore, the scaffolds with $24 \mathrm{~h}$ cell adhesion were transferred to the bioreactor chambers (Figure 1) and incubated at $5 \% \mathrm{CO}_{2}$ and $37^{\circ} \mathrm{C}$ for $24 \mathrm{~h}$ of perfusion in a bioreactor system.

As cell drag was expected to increase with the flow rate, the scaffolds with high and low cell densities were perfused at high and low flow rates, respectively, to guarantee that the viability measurements remained above the detection limit. Thus, the scaffolds seeded with $0.5 \times$ $10^{5}$ cells were perfused with culture medium at the flow rates of $0.005,0.01,0.05$, and $0.1 \mathrm{~mL} / \mathrm{min}$ (Figure 2), while those seeded with $1.5 \times 10^{5}$ cells were perfused at 0.75 , 1.5 , and $3 \mathrm{~mL} / \mathrm{min}$ (Figure 3 ). Two cell cultures were used in these experiments and the number of scaffolds analyzed for each flow rate was 4 per culture.

The schemes of the experimental procedure for cell adhesion and perfusion experiments are presented in Figures 2 and 3, with an indication of the steps in which cell viability and morphological characteristics were determined.

It was also considered that with the reduction of the flow rate, the time required to fill the perfusion system increased. Hence, if the arrival of culture medium to the scaffold occurs with an increased delay, the cells could starve due to the lack of nutrients. Thus, at low flow rates (0.005-0.1 $\mathrm{mL} / \mathrm{min})$, the perfusion chambers were at first partially filled with culture medium at a higher flow rate $(0.5 \mathrm{~mL} / \mathrm{min})$. The flow rate was then decreased to 0.005 , $0.01,0.05$, or $0.1 \mathrm{~mL} / \mathrm{min}$ before the fluid reached the scaffold in any of the chambers.

The average drag ratio was calculated by subtracting the average cell number (determined with the CCK-8 kit) after perfusion from the control average cell number (non-perfused scaffold).

\section{Statistical analysis}

Normal distribution was verified with the combination of the Shapiro-Wilk test and visual inspection of $Q-Q$ plots. Statistical analyses were performed using one-way ANOVA followed by Tukey's post hoc test, and were 

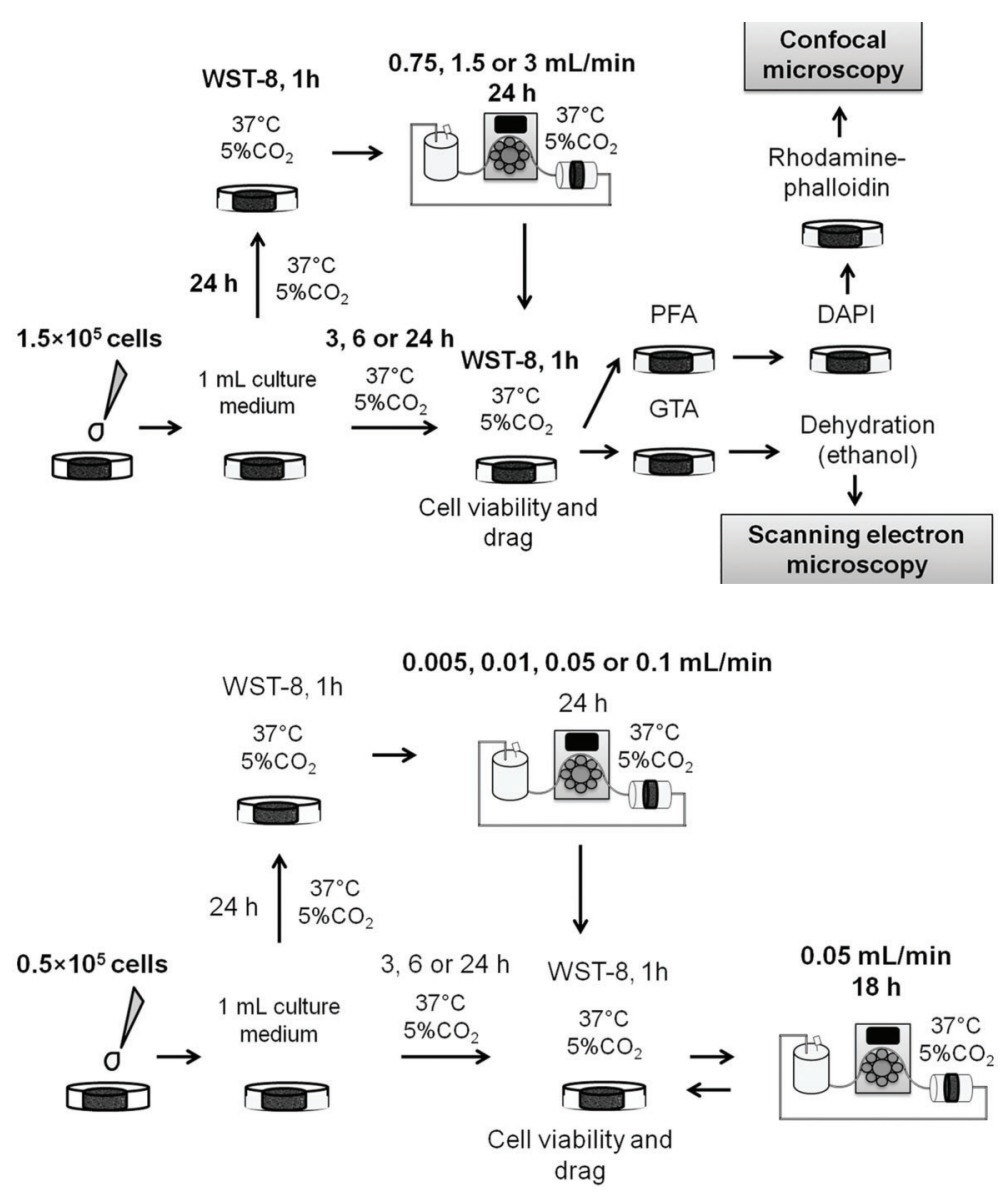

Figure 2. Scheme of the experimental procedure for cell culture with seeding density of $1.5 \times$ $10^{5}$ cells/scaffold (WST-8, PFA, GTA, and DAPI are, respectively, the viability assay, paraformaldehyde, glutaraldehyde, and 4',6-diamidino-2phenylindole).
Figure 3. Scheme of the experimental procedure for cell culture with seeding density of $0.5 \times 10^{5}$ cells/scaffold (WST-8 is the viability assay). carried out with R Statistical Software (version 3.3.2; R Foundation for Statistical Computing, Austria).

\section{Results and Discussion}

\section{Cell morphology}

Figure 4 presents the confocal images of scaffolds seeded with $1.5 \times 10^{5}$ cells and incubated for 3,6 , and $24 \mathrm{~h}$. Additionally, a similar set of images with smaller magnification can be seen as Supplementary Material (Figure S2) to show that the effects observed in Figure 4 do not depend on the specifically focused region. It can be observed that the cell shape was still round after $3 \mathrm{~h}$ of adhesion (Figure $4 \mathrm{~A}$ ). At $6 \mathrm{~h}$ (Figure 4B), the area of actin fibers stained with phalloidin was higher and after $24 \mathrm{~h}$ of adhesion, a spread morphology can be observed (Figure 4C). These results indicate that cytoskeleton spreading was increased with longer adhesion times. As larger cell spreading has been associated with increased focal adhesion size (22) and strength (23), it can be expected that after 24-h adhesion, the cells will be more strongly attached to the fibers of the scaffold.

To evaluate the cell distribution on the scaffold surface, SEM analyses were performed before and after perfusion.
Figure 5 presents SEM images of the scaffolds seeded with $1.5 \times 10^{5}$ cells after 24 -h cell adhesion followed by 24-h perfusion. As can be seen, after 24-h adhesion, the cells organize themselves in agglomerates, forming regions containing a layer of cells on the matrix surface, obstructing the pores. Several studies support that the pore size is responsible for cell infiltration and shear stress is applied to the cells due to the passage of flow in perfusion bioreactors $(24,25)$. In this study, the porosity $(93 \pm 1 \%)$ and pore diameter of the scaffolds $(11.97 \pm$ $4.36 \mu \mathrm{m}$ ) did not necessarily limit cell penetration into the scaffold, if the cell diameter range of 12.2-16.6 $\mu \mathrm{m}$ is considered, as suggested by Suchanek et al. (26). However, with the static seeding, the cells adhered on the fibers covering the scaffold surface and occupying the pore spaces (as shown in Figure 5A). Due to fluid flow, the cells obstructing large pores were detached and dragged with the culture medium under high velocities (Figure 5B), and eventually detached because of the shear stress applied, even under low flow rates.

\section{Cell adhesion and drag}

Figure 6 presents the results of cell number, determined by WST-8, for the adhesion times of 3,6 , and $24 \mathrm{~h}$ 


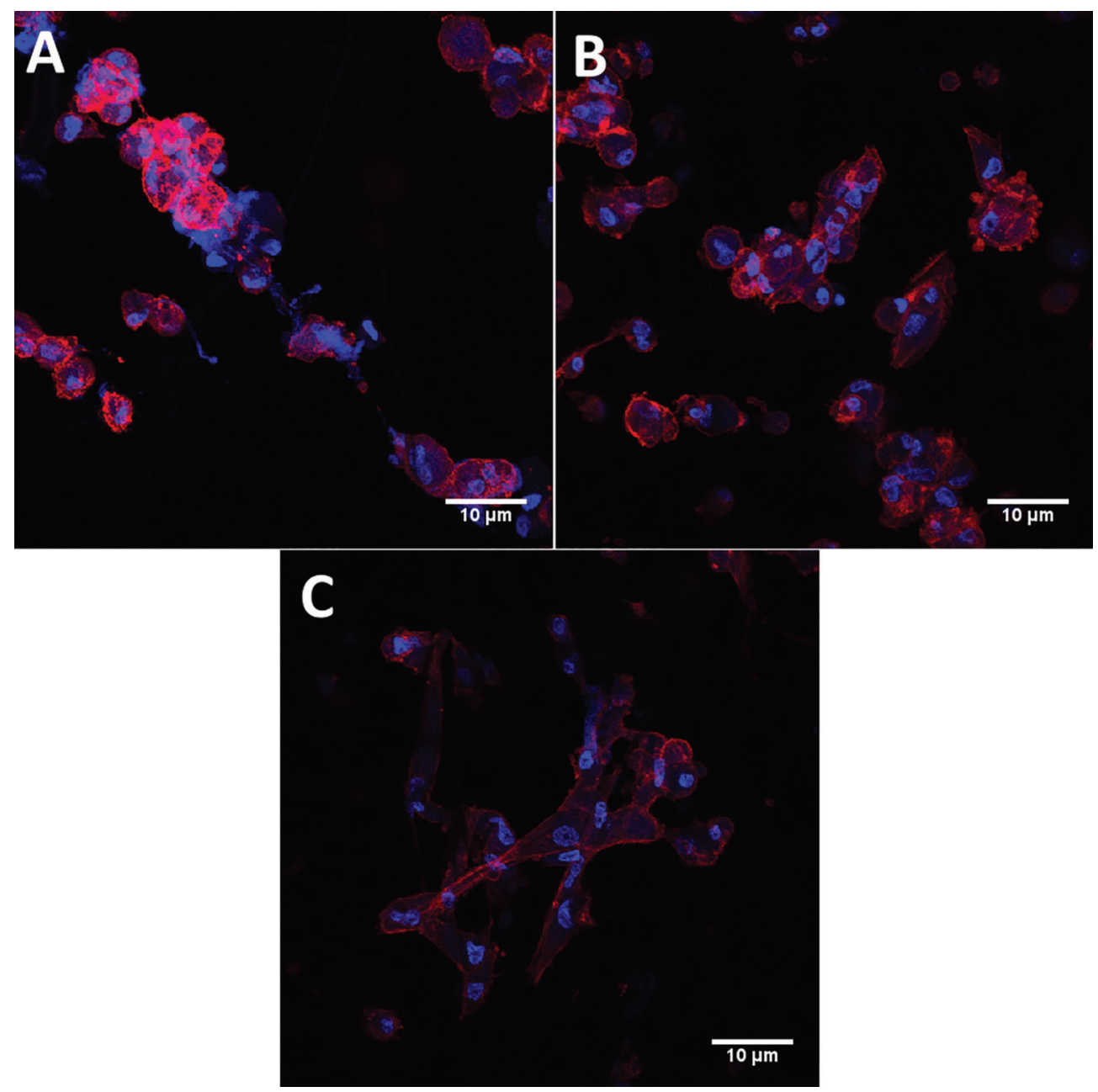

Figure 4. Confocal images of stem cells from culture I in scaffolds seeded with $1.5 \times 10^{5}$ cells and stained with rhodamine-phalloidin (cell cytoskeleton in red) and DAPI (cell nuclei in blue) after $3(A), 6(B)$, and $24 \mathrm{~h}(C)$ cell adhesion. Magnification $\times 40$.

for the scaffolds seeded with a low seeding density $\left(0.5 \times 10^{5}\right.$ cells/scaffold $)$ with the cell cultures I, III, and IV (Figure $6 \mathrm{~A})$ and with a high seeding density $\left(1.5 \times 10^{5} \mathrm{cells} /\right.$ scaffold) with the cell cultures I and II (Figure 6B). For low seeding density, there was no significant effect of adhesion time on cell number determined by cell viability for cultures III and IV, while for culture I a significant $(\mathrm{P}<0.05)$ decrease of mean cell number occurred after 24-h adhesion compared to the lower adhesion times ( 3 and $6 \mathrm{~h}$ ). For high seeding density, there was no significant difference between the values of the mean cell number obtained at the different adhesion times for culture I. For culture II, a decrease of this parameter was also observed between 6 and $24 \mathrm{~h}$, after an initial increase between the adhesion times of 3 and $6 \mathrm{~h}$. However, these results are probably exhibiting a behavior related to the intrinsic characteristics of this specific cell culture, which can be an outcome with primary cell cultures due to the variability between donors (27-31). Harumi Miyagi et al. (31) observed donor-to-donor variation of the expression of extracellular matrix proteins with different human dental pulp stem cells from deciduous teeth, which could justify the different adhesion behavior between the cultures presented in Figure 6. This is in agreement with the fact that mesenchymal stem cells, as anchorage-dependent cells, can undergo cell death by the lack of appropriated attachment to a substrate (32).

A further aspect to be mentioned about Figure 6 is that at both low and high seeding density, significant differences between the cultures regarding the number of cells were observed. This can be a result of the use of cells derived from different individuals. Donor-to-donor variability can occur due to several factors such as donor age and gender, and it has been reported in several studies with primary cultures of human mesenchymal stem cells (27-31). 


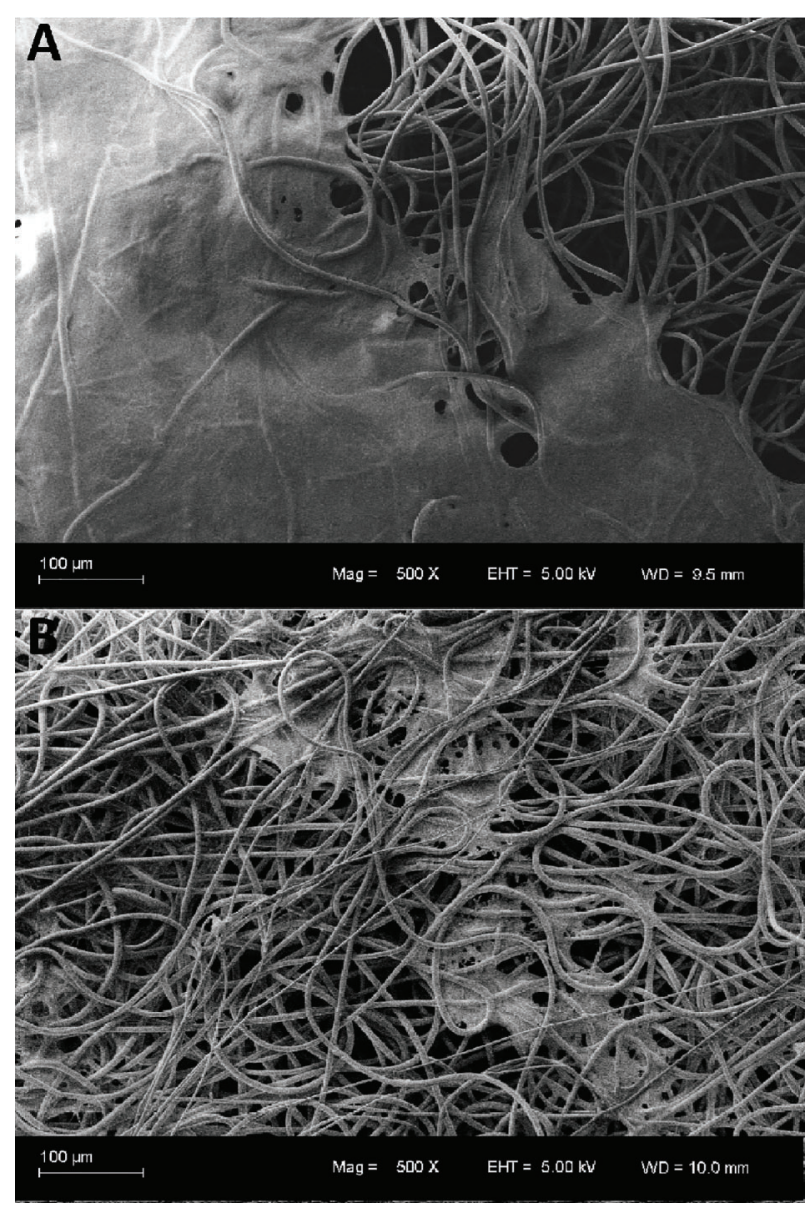

Figure 5. SEM images of scaffolds seeded with $1.5 \times 10^{5}$ cells for $24 \mathrm{~h}$ with cell culture $\mathrm{V}$ before $(A)$ and after $(B)$ culture medium perfusion for $24 \mathrm{~h}$ with a flow rate of $1.5 \mathrm{~mL} / \mathrm{min}$. Magnification $\times 500$.

Figure 7 presents the cell drag percentage calculated from the viable cell numbers (determined by WST-8) obtained for the scaffolds seeded with $0.5 \times 10^{5}$ cells and perfused at a flow rate of $0.05 \mathrm{~mL} / \mathrm{min}$ for $18 \mathrm{~h}$. As can be seen, there was no effect of adhesion time in cell loss under perfusion at $0.05 \mathrm{~mL} / \mathrm{min}$ for cultures I and IV because no significant difference was observed for the different adhesion time groups. In addition, mean cell drag, calculated as the average drag from the three cultures, presented no significant difference between the different adhesion time groups (mean cell drag of $17 \pm 11$, $20 \pm 28$, and $5 \pm 6 \%$ for scaffolds with 3,6 , and $24 \mathrm{~h}$ of adhesion time, respectively). However, culture III presented significantly different cell drag when seeded with 6-h adhesion compared to the other cultures with the same adhesion time $(P<0.001)$, and to the same culture with other adhesion times $(P<0.001)$. Furthermore, culture I presented no cell loss for 6 and $24 \mathrm{~h}$ ( $0 \%$ cell drag). These reduced cell losses can be related to a higher cell
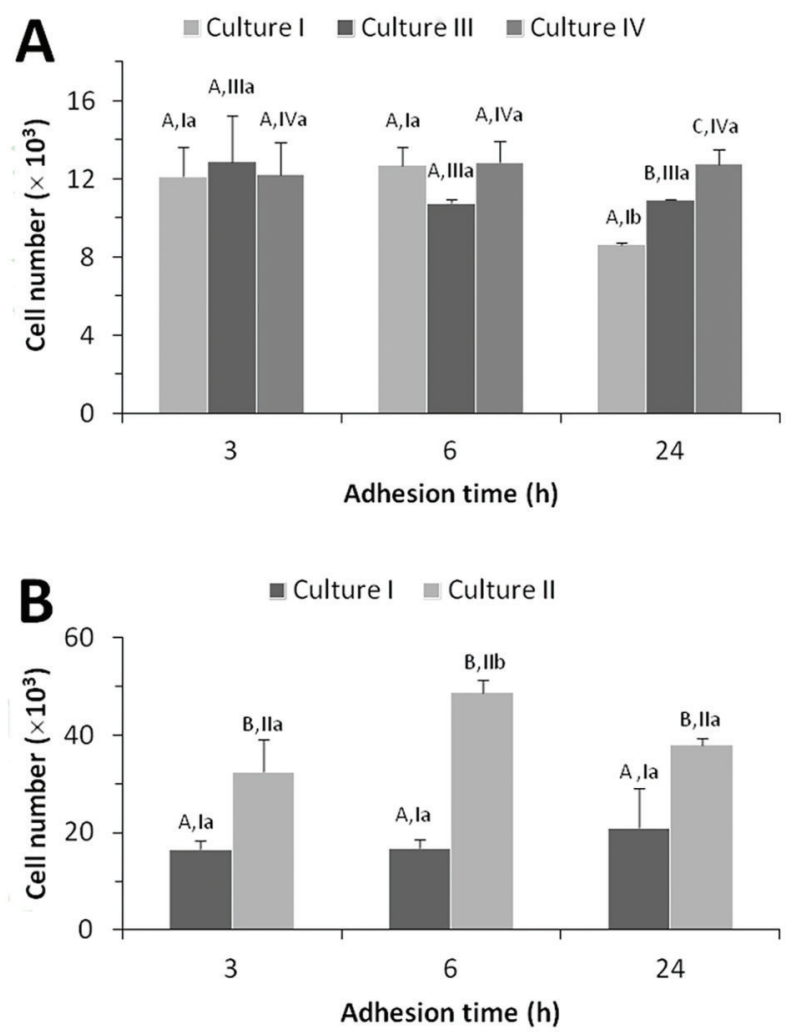

Figure 6. Cell number for different adhesion times for cell cultures I, III, and IV seeded with $0.5 \times 10^{5}$ cells $(A)$ and for cell cultures I and II seeded with $1.5 \times 10^{5}$ cells $(B)$. Data are reported as means $\pm S D$. Different capital letters represent significantly different means for the groups with the same adhesion time. Different lowercase letters preceded by the culture number represent significantly different means for the groups of the same culture with different adhesion times (one-way ANOVA with post hoc Tukey test, $\mathrm{P}<0.05$ ).

spreading observed at 6 and $24 \mathrm{~h}$ of adhesion, observed in Figure 4. Similar results to those obtained for cultures I and IV were observed by van Kooten et al. (33) in bi-dimensional studies using parallel-plate flow chambers, where tangential flow was used to induce shear stress and detach a cell population from a surface. The authors observed that cell adhesion strength, determined as the shear stress level that promotes $50 \%$ of cell detachment, was not sensitive to adhesion time. However, 3D attachment results in different cell morphology (bridged form) than cell adhesion in 2D structures (flat shape) (34). Furthermore, reduced cell adhesion strength and resistance to shear stress can be observed in 3D scaffolds under perfusion conditions because the cells can adhere in an orientation normal for the flow and lead to increased cell detachment under low flow rates (35). However, cell attachment in bi-dimensional structures result in flat form morphology (34). In this study, with the increase of adhesion time, the cells, initially adhered to the fibers (Figure 4A), 


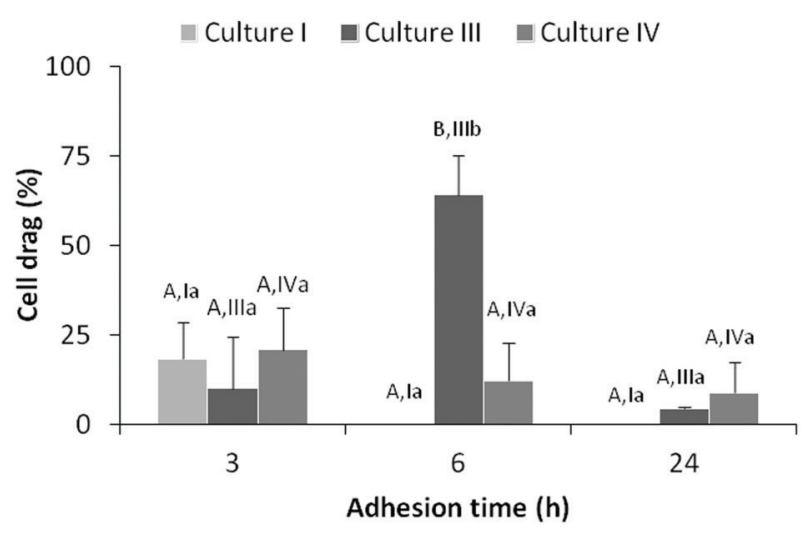

Figure 7. Cell drag in scaffolds seeded with $0.5 \times 10^{5}$ cells with different adhesion times and perfused with a flow rate of $0.05 \mathrm{~mL} / \mathrm{min}$ (shear stress of $2.1 \mathrm{mPa}$ ) for $18 \mathrm{~h}$. Data are reported as means $\pm S D$. Different capital letters represent significantly different means for the groups with the same adhesion time. Different lowercase letters preceded by the culture number represent significantly different means for the groups of the same culture with different adhesion times (one-way ANOVA with post hoc Tukey test, $\mathrm{P}<0.05)$.

stretched through the fibers and the pore space to adhere to other cells and fibers (Figure 4C). This is in accordance with the bridged form morphology (cells attached to more than one fiber) obtained by Binulal et al. (34) for cell attachment in 3D electrospun scaffolds. Furthermore, since the cells adhered filling the pore space (Figure 5), the main orientation to cell attachment in the studied system is expected to be perpendicular to the flow direction, which differs from the parallel flow used by van Kooten et al. (33). According to McCoy and O'Brien (35), reduced cell adhesion strength and resistance to shear stress can be observed in 3D scaffolds under perfusion conditions, because cells can adhere in an orientation normal for the flow and lead to increased cell detachment under low flow rates. This could explain the mechanism of cell drag in a direct perfusion system and the distribution of the cells after perfusion, observed in Figure 5B. Thus, it could be that cultures I and IV presented no enhancement in adhesion strength, with larger adhesion times due to this relationship between cell morphology and flow direction.

Figure 8 presents the values of cell drag percentage calculated from viable cell numbers (determined with WST-8) in the scaffolds from cell cultures I, III, and IV, seeded with $0.5 \times 10^{5}$ cells and perfused with flow rates varying from 0.005 to $0.1 \mathrm{~mL} / \mathrm{min}$ (Figure $8 \mathrm{~A}$ ) and from cultures I, II, III, and V, seeded with $1.5 \times 10^{5}$ cells and perfused with flow rates from 0.75 to $3 \mathrm{~mL} / \mathrm{min}$ (Figure $8 \mathrm{~B}$ ). In all cases, the cell drag percentages were determined after $24-\mathrm{h}$ adhesion followed by $24-\mathrm{h}$ perfusion. As can be seen, at low seeding density, higher flow rates led to a significant increase in cell loss for culture IV $(P<0.001)$. This was also observed for the scaffolds seeded
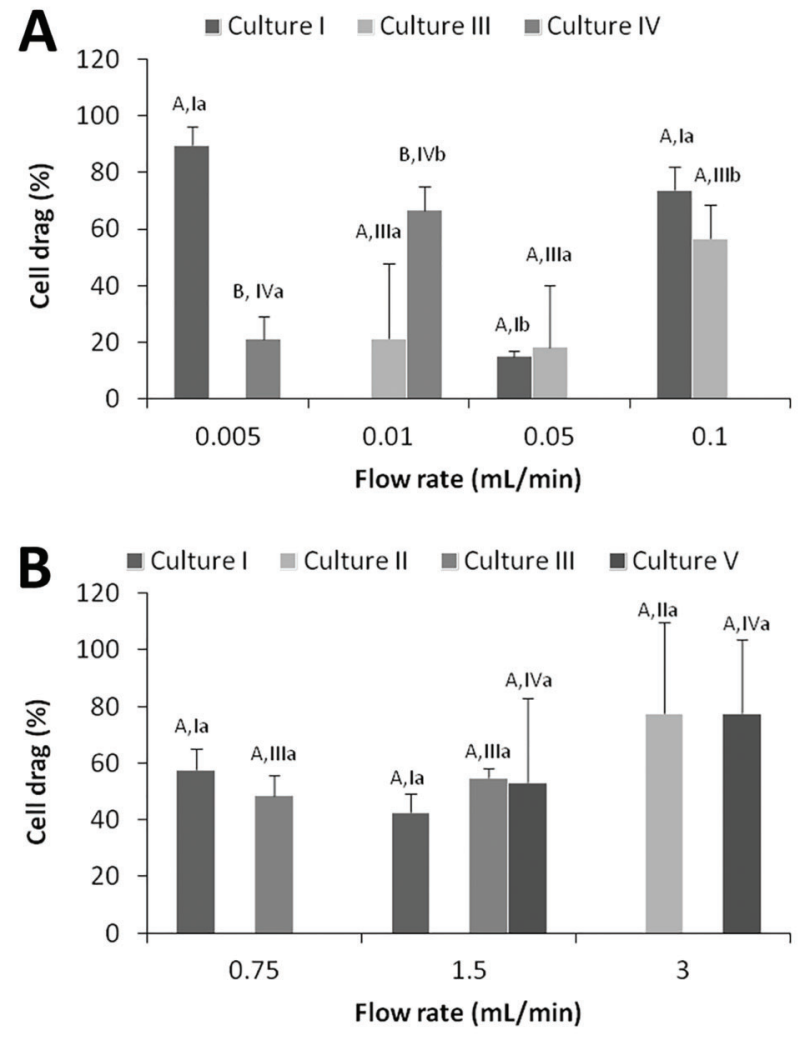

Figure 8. Cell drag percentage in scaffolds seeded with $0.5 \times 10^{5}$ cells from cell cultures I, III, and IV, perfused with flow rates varying from 0.005 to $0.1 \mathrm{~mL} / \mathrm{min}(A)$, and in scaffolds seeded with $1.5 \times 10^{5}$ cells from cultures I, II, III, and V, perfused with flow rates from 0.75 to $3 \mathrm{~mL} / \mathrm{min}(B)$, with $24 \mathrm{~h}$ of adhesion and perfused for $24 \mathrm{~h}$. Data are reported as means \pm SD. Different capital letters represent significantly different means for the groups with the same flow rate. Different lowercase letters preceded by the culture number represent significantly different means for the groups of the same culture with different flow rates (one-way ANOVA with post hoc Tukey test, $\mathrm{P}<0.05$ ).

$\left(0.5 \times 10^{5}\right.$ cells $)$ with cultures I and III $(P<0.01)$ compared to the results with flow rates of 0.05 and $0.1 \mathrm{~mL} / \mathrm{min}$. On the other hand, culture I, when seeded at a low density, presented higher cell loss for the flow rate of $0.005 \mathrm{~mL} / \mathrm{min}$ compared to the flow rate of $0.05 \mathrm{~mL} / \mathrm{min}(\mathrm{P}<0.0001)$. For very low flow rates as $0.005 \mathrm{~mL} / \mathrm{min}$, the loss of cell viability (observed for culture I) is probably not provoked by shear stress but by the reduction of oxygen delivery inside the perfusion chamber, because of the decreased convection. Decreased oxygen concentrations have already been reported with reduced convection in perfusion bioreactors $(36,37)$. Furthermore, the cell drag differences observed between the cultures can be a result of the use of cells derived from different individuals, as previously mentioned. Interestingly, at higher flow rates and seeding density there was no significant difference in cell loss between the different groups with different flow rates 
Table 1. Mean cell drag and shear stress in scaffolds seeded with $0.5 \times 10^{5}$ and $1.5 \times 10^{5}$ cells with $24 \mathrm{~h}$ of cell adhesion and perfused for $24 \mathrm{~h}$.

\begin{tabular}{lccccccc}
\hline & \multicolumn{3}{c}{$0.5 \times 10^{5}$ cells } & \multicolumn{3}{c}{$1.5 \times 10^{5}$ cells } \\
\hline Flow rate $(\mathrm{mL} / \mathrm{min})$ & 0.005 & 0.01 & 0.05 & 0.1 & 0.75 & 1.5 & 3.0 \\
Shear stress (mPa) & 0.2 & 0.40 & 2.10 & 4.1 & 30.9 & 61.9 & 123.7 \\
Mean cell drag (\%) & 63 & 44 & 24 & 65 & 54 & 50 & 78 \\
Standard deviation (\%) & 35 & 30 & 29 & 13 & 9 & 18 & 26 \\
Cultures & I, IV & III, IV & I, III & I, III & I, III & I, III, V & II, V \\
\hline
\end{tabular}

and/or cultures (Figure 8B). This can be due to the higher seeding density, which results in higher cell number at the beginning of the perfusion and in an initial reduction of the permeability of the scaffold due to superficial pore obstruction. With less free space for fluid flow, the pore diameter and porosity of the scaffold are reduced, increasing shear stress levels (as in accordance with Equation 2) and cell drag. Additionally, it was observed that as cells are detached by the passage of flow through the pores, the amount of cells and debris in suspension is increased (results not shown). It is possible that, with a high flow rate, the high quantity of cellular particles in suspension affected the viscosity of the culture medium, also increasing the shear stress levels (as in accordance with Equation 2). The combination of these factors with the variability in seeding efficiency between the cultures with high seeding density (observed in Figure 6B) could have homogenized the cell drag with different flow rates.

Table 1 shows the values of mean cell drag percentage and shear stress (Equation 2) obtained with the scaffolds seeded with 0.5 and $1.5 \times 10^{5}$ cells for $24-\mathrm{h}$ adhesion and perfused with flow rates from 0.005 to $3 \mathrm{~mL} / \mathrm{min}$ for $24 \mathrm{~h}$. The lowest cell drag (24\%) was obtained with a flow rate of $0.05 \mathrm{~mL} / \mathrm{min}$, which results in a shear stress of $2.1 \mathrm{mPa}$ on the pore walls. This result indicates that there is an optimal flow rate value for each system, providing this flow rate does not provoke cell starvation or high cell detachment. However, no significant difference was observed for mean cell drag with different flow rates, which could be due to the high standard deviation of each group and donor-to-donor variability. Fibrous (but not electrospun) scaffolds with fiber diameters of $20 \mu \mathrm{m}$ presented cell detachment values (62 and $69 \%$ ) at flow rates of 0.5 and $1 \mathrm{~mL} / \mathrm{min}$ (38) similar to those presented in Table 1 at flow rates of 0.75 and $1.5 \mathrm{~mL} / \mathrm{min}$. On the other hand, high

\section{References}

1. Khorshidi $\mathrm{S}$, Solouk $\mathrm{A}$, Mirzadeh $\mathrm{H}$, Mazinani $\mathrm{S}$, Lagaron $\mathrm{JM}$, Sharifi S, et al. A review of key challenges of electrospun scaffolds for tissue-engineering applications. J Tissue Eng Regen Med 2016; 10: 715-738, doi: 10.1002/term.1978.

2. Vaquette C, Cooper-White JJ. Increasing electrospun scaffold pore size with tailored collectors for improved cell penetration. shear stresses (values up to 56 and $57 \mathrm{mPa}$ ), which are close to those calculated in this work for a flow rate of $1.5 \mathrm{~mL} / \mathrm{min}$, have been shown to provoke cell washout and apoptosis $(10,39)$. This could justify the high cell loss presented in Table 1 at high flow rates, as cell drag was calculated based on cell viability, being the possible reason for not observing the general trend reported in direct perfusion systems (i.e., increase in cell detachment with the increase of flow rate) (40) in the present work.

The detachment of human dental pulp stem cells from polycaprolactone electrospun scaffolds under direct perfusion was studied for different flow rates, adhesion times and seeding densities. Higher adhesion time led to higher cell spreading in static conditions and reduced cell detachment under perfusion. The seeding density affected cell distribution on the scaffold surface and the sensitivity of the cells to the flow rate. High shear stress and flow rate values resulted in high cell detachments, but too low flow rates were closer to operational constraints that could result in loss of cell viability. Thus, the lowest flow rate within a safe operating range might be more suitable for the culture of human dental pulp stem cells in electrospun scaffolds.

\section{Supplementary material}

Click here to view [pdf].

\section{Acknowledgments}

The authors wish to thank the Stem Cell Research Institute (Instituto de Pesquisa com Células-tronco), the Coordination for the Improvement of Higher Level Personnel (CAPES), the Study and Project Financer (FINEP) for financial support.
Acta Biomater 2011; 7: 2544-2557, doi: 10.1016/j.actbio.2011. 02.036.

3. Ruckh TT, Kumar K, Kipper MJ, Popat KC. Osteogenic differentiation of bone marrow stromal cells on poly( $\varepsilon$-caprolactone) nanofiber scaffolds. Acta Biomater 2010; 6: 2949-2959, doi: 10.1016/j.actbio.2010.02.006. 
4. Gluck JM. Electrospun nanofibrous poly( $\varepsilon$-caprolactone) (PCL) scaffolds for liver tissue engineering. [Master's thesis]. Raleigh: Graduate Faculty of North Carolina State University; 2007.

5. Pham QP, Sharma U, Mikos AG. Electrospun Poly(ع-caprolactone) microfiber and multilayer nanofiber/microfiber scaffolds: characterization of scaffolds and measurement of cellular infiltration. Biomacromolecules 2006; 7: 2796-2805, doi: 10.1021/bm060680j.

6. Bancroft GN, Sikavitsas VI, Mikos AG. Design of a flow perfusion bioreactor system for bone tissue-engineering applications. Tissue Eng 2003; 9: 549-554, doi: 10.1089/ 107632703322066723.

7. Markhoff J, Wieding J, Weissmann V, Pasold J, JonitzHeincke A, Bader R. Influence of different three-dimensional open porous titanium scaffold designs on human osteoblasts behavior in static and dynamic cell investigations. Materials 2015; 8: 5490-5507, doi: 10.3390/ma8085259.

8. Yeatts $A B$. Tubular perfusion system bioreactor for the dynamic culture of human mesenchymal stem cells. [PhD thesis]. College Park: Faculty of the Graduate School of the University of Maryland; 2012.

9. An J, Leeuwenburgh SCG, Wolke JGC, Jansen JA. Effects of stirring and fluid perfusion on the in vitro degradation of calcium phosphate cement/PLGA composites. Tissue Eng Part C Methods 2015; 21: 1171-1177, doi: 10.1089/ten. tec.2015.0016.

10. Cartmell SH, Porter BD, García AJ, Guldberg RE. Effects of medium perfusion rate on cell-seeded three-dimensional bone constructs in vitro. tissue Eng 2003; 9: 1197-1203, doi: 10.1089/10763270360728107.

11. Sinlapabodin S, Amornsudthiwat $P$, Damrongsakkul S, Kanokpanont S. An axial distribution of seeding, proliferation, and osteogenic differentiation of MC3T3-E1 cells and rat bone marrow-derived mesenchymal stem cells across a 3D Thai silk fibroin/gelatin/hydroxyapatite scaffold in a perfusion bioreactor. Mater Sci Eng C 2016; 58: 960-970, doi: 10.1016/j.msec.2015.09.034.

12. Datta N, Pham QP, Sharma U, Sikavitsas VI, Jansen JA, Mikos AG. In vitro generated extracellular matrix and fluid shear stress synergistically enhance 3D osteoblastic differentiation. Proc Natl Acad Sci 2006; 103: 2488-2493, doi: 10.1073/pnas.0505661103.

13. Grayson WL, Bhumiratana S, Cannizzaro C, Chao P-HG, Lennon DP, Caplan Al, et al. Effects of initial seeding density and fluid perfusion rate on formation of tissue-engineered bone. Tissue Eng Part A 2008; 14: 1809-1820, doi: 10.1089/ ten.tea.2007.0255.

14. Jagodzinski M, Breitbart A, Wehmeier M, Hesse E, Haasper $C$, Krettek $C$, et al. Influence of perfusion and cyclic compression on proliferation and differentiation of bone marrow stromal cells in 3-dimensional culture. J Biomech 2008; 41: 1885-1891, doi: 10.1016/j.jbiomech.2008.04.001.

15. Werle SB, Lindemann D, Steffens D, Demarco FF, de Araujo FB, Pranke P, et al. Carious deciduous teeth are a potential source for dental pulp stem cells. Clin Oral Investig 2016; 20: 75-81, doi: 10.1007/s00784-015-1477-5.

16. Santoro M, Lamhamedi-Cherradi S-E, Menegaz BA, Ludwig JA, Mikos AG. Flow perfusion effects on three-dimensional culture and drug sensitivity of Ewing sarcoma. Proc Natl Acad Sci 2015; 112: 10304-10309, doi: 10.1073/pnas.1506684112.
17. Yassin MA, Leknes KN, Pedersen TO, Xing Z, Sun Y, Lie $S A$, et al. Cell seeding density is a critical determinant for copolymer scaffolds-induced bone regeneration. $J$ Biomed Mater Res Part A 2015; 103: 3649-3658, doi: 10.1002/jbm. a.35505.

18. Cheng Y-L, Chen Y-W, Wang K, Shie M-Y. Enhanced adhesion and differentiation of human mesenchymal stem cell inside apatite-mineralized/poly(dopamine)-coated poly ( $\varepsilon$-caprolactone) scaffolds by stereolithography. J Mater Chem B 2016; 4: 6307-6615, doi: 10.1039/C6TB01377E.

19. Kafi MA, Phanny Y, Nakamuta Y, Todo M. Proliferation behavior of mesenchymal stem cells in peptide functionalized chitosan scaffolds. The 15th International Conference on Biomedical Engineering: ICBME 2013, 2013 Dec 4-7, Singapore Cham: Springer International Publishing; 2014. p. 279-282.

20. Serra T. Development of 3d-printed biodegradable composite scaffolds for tissue engineering applications. [PhD thesis]. Barcelona: Universitat Politècnica de Cataluny; 2014.

21. Banik BL, Riley TR, Platt CJ, Brown JL. Human mesenchymal stem cell morphology and migration on microtextured titanium. Front Bioeng Biotechnol 2016; 4: 41, doi: 10.3389/ fbioe.2016.00041.

22. Kim D-H, Wirtz D. Predicting how cells spread and migrate. Cell Adh Migr 2013; 7: 293-296, doi: 10.4161/cam.24804.

23. Christophis C, Grunze M, Rosenhahn A. Quantification of the adhesion strength of fibroblast cells on ethylene glycol terminated self-assembled monolayers by a microfluidic shear force assay. Phys Chem Chem Phys 2010; 12: 4498, doi: 10.1039/b924304f.

24. Balguid A, Mol A, van Marion MH, Bank RA, Bouten CVC, Baaijens FPT. Tailoring fiber diameter in electrospun poly $(\varepsilon$-Caprolactone) scaffolds for optimal cellular infiltration in cardiovascular tissue engineering. Tissue Eng Part $A$ 2009; 15: 437-444, doi: 10.1089/ten.tea.2007.0294.

25. Lynch ME, Fischbach C. Biomechanical forces in the skeleton and their relevance to bone metastasis: Biology and engineering considerations. Adv Drug Deliv Rev 2014; 79-80: 119-134, doi: 10.1016/j.addr.2014.08.009.

26. Suchanek J, Soukup T, Visek B, Ivancakova R, Kucerova L, Mokry J. Dental pulp stem cells and their characterization. Biomed Pap Med Fac Univ Palacky Olomouc Czech Repub 2009; 153: 31-35, doi: 10.5507/bp.2009.005.

27. Capra E, Beretta R, Parazzi V, Viganò M, Lazzari L, Baldi A, et al. Changes in the proteomic profile of adipose tissuederived mesenchymal stem cells during passages. Proteome Sci 2012; 10: 46, doi: 10.1186/1477-5956-10-46.

28. Siddappa R, Licht R, van Blitterswijk C, de Boer J. Donor variation and loss of multipotency during in vitro expansion of human mesenchymal stem cells for bone tissue engineering. J Orthop Res 2007; 25: 1029-1041, doi: 10.1002/ jor.20402.

29. Heathman TRJ, Rafiq QA, Chan AKC, Coopman K, Nienow AW, Kara B, et al. Characterization of human mesenchymal stem cells from multiple donors and the implications for large scale bioprocess development. Biochem Eng J 2016; 108: 14-23, doi: 10.1016/j.bej.2015.06.018.

30. Sundelacruz S, Levin M, Kaplan DL. Comparison of the depolarization response of human mesenchymal stem cells from different donors. Sci Rep 2015; 5: 18279, doi: 10.1038/ srep18279. 
31. Harumi Miyagi SP, Kerkis I, da Costa Maranduba CM, Gomes CM, Martins MD, Marques MM. Expression of extracellular matrix proteins in human dental pulp stem cells depends on the donor tooth conditions. J Endod 2010; 36: 826-831, doi: 10.1016/j.joen.2010.02.020.

32. Engbers-Buijtenhuijs $P$, Kamphuis M, van der Sluijs Veer $G$, Haanen C, Poot AA, Feijen J, et al. A novel time resolved fluorometric assay of anoikis using Europium-labelled Annexin $\mathrm{V}$ in cultured adherent cells. Apoptosis 2005; 10: 429-437, doi: 10.1007/s10495-005-0816-4.

33. van Kooten TG, Schakenraad JM, van der Mei HC, Dekker A, Kirkpatrick CJ, Busscher HJ. Fluid shear induced endothelial cell detachment from glass - influence of adhesion time and shear stress. Med Eng Phys 1994; 16: 506-512, doi: 10.1016/1350-4533(94)90077-9.

34. Binulal NS, Deepthy M, Selvamurugan N, Shalumon KT, Suja S, Mony U, et al. Role of nanofibrous poly(Caprolactone) scaffolds in human mesenchymal stem cell attachment and spreading for in vitro bone tissue engineering-response to osteogenic regulators. Tissue Eng Part A 2010; 16: 393-404, doi: 10.1089/ten.tea.2009.0242.

35. McCoy RJ, O'Brien FJ. Influence of shear stress in perfusion bioreactor cultures for the development of three-dimensional bone tissue constructs: a review. Tissue Eng Part B Rev 2010; 16: 587-601, doi: 10.1089/ten.teb. 2010.0370.

36. Coletti F, Macchietto S, Elvassore N. Mathematical modeling of three-dimensional cell cultures in perfusion bioreactors. Ind Eng Chem Res 2006; 45: 8158-8169, doi: 10.1021/ie051144v.

37. Pathi $P, M a T$, Locke BR. Role of nutrient supply on cell growth in bioreactor design for tissue engineering of hematopoietic cells. Biotechnol Bioeng 2005; 89: 743-758, doi: 10.1002/bit.20367.

38. Alvarez-Barreto JF, Linehan SM, Shambaugh RL, Sikavitsas VI. Flow perfusion improves seeding of tissue engineering scaffolds with different architectures. Ann Biomed Eng 2007; 35: 429-442, doi: 10.1007/s10439-006-9244-z.

39. Raimondi MT, Moretti M, Cioffi M, Giordano C, Boschetti F, Laganà $K$, et al. The effect of hydrodynamic shear on 3D engineered chondrocyte systems subject to direct perfusion. Biorheology 2006; 43: 215-222.

40. Raimondi MT, Bertoldi S, Caddeo S, Farè S, Arrigoni C, Moretti M. The effect of polyurethane scaffold surface treatments on the adhesion of chondrocytes subjected to interstitial perfusion culture. Tissue Eng Regen Med 2016; 13: 364-374, doi: 10.1007/s13770-016-9047-8. 